Revista Brasileira de Farmacognosia Brazilian Journal of Pharmacognosy 21(2): 234-238, Mar./Apr. 2011

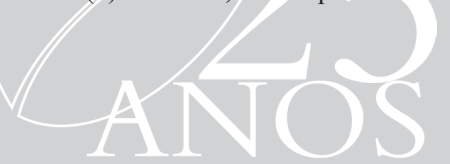

Article

Received 20 Dec 2010

Accepted 1 Feb 2011

Available online 1 Apr 2011

Keywords:

Canistrocarpus cervicornis

seaweed

diterpenes

Lachesis muta

snake venom

antiophidian

ISSN 0102-695X

doi: 10.1590/S0102-695X2011005000048

\section{Anti-snake venom effect of secodolastane diterpenes isolated from Brazilian marine brown alga Canistrocarpus cervicornis against Lachesis muta venom}

\author{
Thaisa Francielle S. Domingos, ${ }^{1,2}$ Magui Aparecida Vallim, ${ }^{1}$ \\ Carla Carvalho, ${ }^{2}$ Eladio Flores Sanchez, ${ }^{3}$ Valéria Laneuville \\ Teixeira, ${ }^{1}$ André Lopes Fuly ${ }^{*, 2}$
}

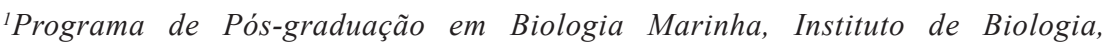 \\ Universidade Federal Fluminense, Brazil, \\ ${ }^{2}$ Departamento de Biologia Celular e Molecular, Instituto de Biologia, Universidade \\ Federal Fluminense, Brazil, \\ ${ }^{3}$ Fundação Ezequiel Dias, Centro de Pesquisa e Desenvolvimento, Brazil.
}

\begin{abstract}
The effect of a Brazilian algae extract and also a mixture of two secodolastane diterpenes (linearol/isolinearol) that were isolated from the marine brown alga Canistrocarpus cervicornis were evaluated against biological activities of Lachesis muta snake venom. In vitro assays showed that the crude extract and the diterpenes were able to inhibit the clotting and proteolytic activity induced by $L$. muta crude venom, but not the hemolytic activity. However, only the diterpenes inhibited the hemolysis caused by a purified phospholipase $\mathrm{A}_{2}$ previously isolated from $L$. muta venom, denoted LM-PLA - I. Interestingly, the crude algal extract and the diterpenes were able to protect mice from hemorrhage induced by $L$. muta venom. Thus, we may conclude that marine algae are rich and powerful sources of molecules that may be used against L. muta accidents in order to improve treatment of envenomation by this snake.
\end{abstract}

\section{Introduction}

The oceans exhibit many living organisms that in turn produce different substances with several pharmacological properties, such as antimicrobial, antiviral, anticancer, antimalarial, antituberculosis, antilonomic and antiophidic (González et al., 2001; Rocha et al., 2007; Jongaramruong \& Kongkam, 2007; Cirne-Santos et al., 2008; Domingos et al., 2009; Moura et al., 2010). Species of the family Dictyotaceae produce a large array of bioactive secondary metabolites that have biological (defensive action against herbivores) and pharmacological activities. Phycochemical studies have been undertaken on this family, resulting in the isolation of more than 300 diterpenes from at least 35 species collected all over the world (Vallim et al., 2005). The brown seaweed Canistrocarpus cervicornis (Kützing) De Paula \& De Clerck (formely Dictyota cervicornis Kützing) possesses a biosynthetic pathway that produces dolastane and seco-dolastane diterpenes, encompassing a total of more than 25 compounds (Teixeira et al., 1986; de Oliveira et al., 2008). Not surprisingly, some of these diterpenes are biologicallyactive molecules (Bianco et al., 2009; Moura et al., 2010).

Ophidic accidents represent a serious health problem in the world because of their high incidence and the sequelae of poisoning. Snake venoms are composed of a complex mixture that induces a wide range of biological activities. Envenomation by L. muta snakes results in haemostatic disturbs, hemorrhage, edema, necrosis and hemolysis (Jorge et al., 1997) and is characterized by high lethality and morbidity indexes (Ministério da Saúde, 2001). The regular treatment for snakebite is the parenteral administration of antiophidian serum (antivenom) obtained from hyperimmunized equine serum. The antivenom efficiently neutralizes the systemic toxic effects, but, however, has some disadvantages. It can induce adverse reactions ranging from mild symptoms to serious ones and it does not neutralize the local tissue damage (da Silva et al., 2007). Thus, it is important to search for new snake venom inhibitors, either synthetic or from natural sources, to complement the traditional serum therapy. 
The objective of this work is to evaluate the effect of diterpenes isolated from Brazilian $C$. cervicornis marine alga against in vivo and in vitro activities of $L$. muta snake venom, as well as against the phospholipase $\mathrm{A}_{2}$ enzyme (denoted LM-PLA2-I) previously isolated from its venom (Fuly et al., 1997).

\section{Materials and Methods}

Algae material

Specimens of Canistrocarpus cervicornis (Dictyotaceae, Phaeophyta) were collected during May, 2006, at Praia do Forno, in the city of Armação de Búzios, located in the north of Rio de Janeiro State $\left(22^{\circ} 45^{\prime} 42^{\prime \prime} \mathrm{S}\right.$ and $41^{\circ} 52^{\prime} 27^{\prime \prime} \mathrm{W}$ ), Brazil, at depths ranging from 0.3 and $2 \mathrm{~m}$ by snorkeling. The seaweeds were washed with local sea water, separated from sediments, epiphytes and other associated organisms. Voucher specimens are deposited at the herbarium of the Universidade do Estado do Rio de Janeiro (HRJ 10754).

\section{Algae compound isolation}

The air-dried algal material ( $100 \mathrm{~g})$ was extracted in $\mathrm{CH}_{2} \mathrm{Cl}_{2}(100 \%)$ at room temperature for seven days, yielding a 14 g-dichloromethane crude extract. The mixture of diterpenes isolinearol (1)/linearol (2) (25.8 $\mathrm{mg}$ ) was obtained according to Teixeira et al. (1986) with some modifications, then dissolved in dimethylsulfoxide (DMSO) to perform biological assays.

\section{Snake venom and animals}

L. muta snake lyophilized venom was provided from Fundação Ezequiel Dias, Belo Horizonte, MG, Brazil, and LM-PLA $-\mathrm{I}$ was isolated accordingly to Fuly et al. (1997; 2002). Balb/c mice (18-20 g) were obtained from the Núcleo de Animais de Laboratório of the Universidade Federal Fluminense (CEPA: 200/10). They were housed under controlled conditions of temperature $\left(24 \pm 1^{\circ} \mathrm{C}\right)$ and light and all of the experiments performed were approved by the UFF Institutional Committee for Ethics in Animal Experimentation and were in accordance with the guidelines of the Brazilian Committee for Animal Experimentation (COBEA).

Assays

\section{Antihemolytic activity}

The degree of hemolysis of L. muta venom or LM-PLA 2 -I was determined by the indirect hemolytic test using human erythrocytes and hen's egg yolk emulsion as substrate (Fuly et al., 2002). The amount of
L. muta venom $(\mu \mathrm{g} / \mathrm{mL})$ that produced $100 \%$ hemolysis was denoted as the Minimum Indirect Hemolytic Dose (MIHD). Inhibitory experiments were performed by preincubating C. cervicornis extract or diterpenes with one MIHD for $30 \mathrm{~min}$ at room temperature prior to evaluating the hemolytic activity.

\section{Anticlotting activity}

The clotting activity of L. muta venom was determined on an Amelung Model KC4Acoagulometer (Labcon, Germany). Different concentrations of $L$. muta venom were mixed with bovine fibrinogen solution $(2 \mathrm{mg} / \mathrm{mL}$, final concentration) and the amount of venom $(\mu \mathrm{g} / \mathrm{mL})$ that clots fibrinogen in $60 \mathrm{~s}$ was denoted as the Minimum Coagulant Dose (MCD). To evaluate the inhibitory effect, C. cervicornis crude extract or diterpenes were preincubated for $30 \mathrm{~min}$ at room temperature with one MCD of venom; the mixture was then added to fibrinogen and the clotting time recorded. Control experiments were performed in parallel by adding DMSO $(0,5 \% \mathrm{v} / \mathrm{v}$, final concentration $)$ or saline preincubated with venom instead of diterpenes.

\section{Antihemorrhagic activity}

Hemorrhagic lesions produced by L. muta venom were quantified using a procedure described by (Kondo et al., 1960), with minor modifications. Briefly, samples were injected intradermally (i.d.) into the abdominal skin of mice. Two hours later, the animals were euthanized, the abdominal skin removed, stretched and inspected for visual changes in the internal aspect in order to localize hemorrhagic spots. Hemorrhage was quantified as the Minimum Hemorrhagic Dose (MHD), defined as the amount of venom $(\mathrm{mg} / \mathrm{kg})$ able to produce a hemorrhagic halo of $10 \mathrm{~mm}$ (Nikai et al., 1984). The inhibitory effect of diterpenes and C. cervicornis extract was investigated by incubating compounds with one MHD of L. muta venom for $30 \mathrm{~min}$ at room temperature and the mixture was then injected into mice and hemorrhage measured. Hemorrhagic activity was expressed as the mean diameter (in millimeter) of the hemorrhagic halo induced by L. muta venom in the absence and presence of the diterpenes or $C$. cervicornis crude extract. Negative control experiments were performed by injecting DMSO $(0,9 \% \mathrm{v} / \mathrm{v}$, final concentration) or saline.

\section{Antiproteolytic activity}

Proteolytic activity of $L$. muta venom was determined using azocasein as substrate $(0.2 \% \mathrm{w} / \mathrm{v}$, in $20 \mathrm{mM}$ Tris- $\mathrm{HCl}, 8 \mathrm{mM} \mathrm{CaCl}_{2}, \mathrm{pH} \mathrm{8.8),} \mathrm{with} \mathrm{minor}$ 
modification (Garcia et al., 1978). An Effective Concentration (EC) was defined as the amount of venom $(\mu \mathrm{g} / \mathrm{mL})$ able to produce a variation of about 0.2 OD units at A 420. Diterpenes or C. cervicornis extract were preincubated with two EC of $L$. muta venom for $30 \mathrm{~min}$ at room temperature and then proteolysis was measured.

\section{Statistical analysis}

Results are expressed as means \pm SEM obtained with the indicated number of animals or experiments performed. The statistical significance of differences among experimental groups was evaluated using the Student's t test and $p$ values of $\leq 0.05$ were considered statistically significant.

\section{Results and Discussion}

The search for bioactive molecules in marine organisms has been growing in the last few years. These molecules are the products of secondary metabolism and display pharmacological properties (Mayer et al., 2007; Cirne-Santos et al., 2008; Abrantes et al., 2010) as well as ecological functions (Bianco et al., 2009). A previous study demonstrated that L. muta venom displayed phospholipase $\mathrm{A}_{2}$ (indirect hemolytic activity), hemorrhagic, clotting and proteolytic activities (Fuly et al., 1993). The ability of a dolastane diterpene isolated from $C$. cervicornis alga to inhibit biological activities of L. muta was investigated (Moura et al., 2010). The authors showed that this diterpene inhibited $L$. muta activities (hemolysis, proteolysis, hemorrhage and coagulation). Herein, we evaluated the ability of $C$. cervicornis algal extract and a mixture of its isolated secodolastane diterpenes isolinearol (1)/linearol (2) to neutralize those biological activities (hemolysis, clotting, hemorrhage and proteolysis) of L. muta venom as well. However, it is worth emphasizing that the $C$. cervicornis extracts were collected in different areas; the algae used by Moura et al. (2010) were collected in Angra dos Reis, Rio de Janeiro state, while in this work, C. cervicornis was collected at Armação dos Búzios, RJ. As known from the literature, the chemical composition of marine algae can vary according to the local of collection (Teixeira et al., 1990; Freitas et al., 2007; Ortiz-Ramírez et al., 2008). C. cervicornis extract $(360 \mu \mathrm{g} / \mathrm{mL})$ and its isolated diterpenes $(720 \mu \mathrm{g} / \mathrm{mL})$ were not able to inhibit hemolysis induced by L. muta venom (36 $\mu \mathrm{g} / \mathrm{mL}$ ) (Table 1). On the other hand, the diterpenes isolinearol/linearol (1800 $\mu \mathrm{g} / \mathrm{mL})$ inhibited ca. $60 \%$ of the hemolytic activity of LM-PLA $-\mathrm{I}(90 \mu \mathrm{g} / \mathrm{mL})$ (Table 1). Such different inhibitory profiles may be

explained by the fact that L. muta venom contains phospholipase $\mathrm{A}_{2}\left(\mathrm{PLA}_{2}\right)$ isoforms and, naturally, all of them contribute to the degree of hemolysis induced by venom (Fuly et al., 2002; Damico et al., 2008). As shown here, the diterpenes were able to inhibit one of these isoforms, LM-PLA - I (Table 1). This is in contrast to the results of Moura (2010), whose $C$. cervicornis extract (from algae collected in Angra dos Reis) inhibited hemolysis of L. muta venom. This reinforces the fact that the geographical position of collection of marine algae should be considered in bioprospeccion studies. The $C$. cervicornis extract, diterpenes or DMSO $(1 \% \mathrm{v} / \mathrm{v}$, final concentration) alone were not able to induce hemolysis; and DMSO did not interfere with the activity of $L$. muta venom or LM-PLA $\mathrm{A}_{2}$-I (data not shown).

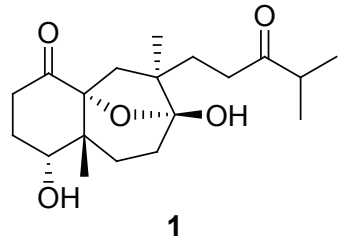

As shown in Figure 1A, C. cervicornis extract and the isolated diterpenes inhibited proteolysis by L. muta venom $(1.6 \mu \mathrm{g} / \mathrm{mL})$ with different potencies. The diterpenes presented higher inhibitory activity than the $C$. cervicornis extract, Thus, at a 1:60 venom:alga ratio, 18 and $95 \%$ inhibition were observed for C. cervicornis extract and for diterpene, respectively. Only at a 1:180 ratio did C. cervicornis extract fully inhibit the proteolytic activity of the venom (Figure 1A). Envenomation by L. muta venom usually produces hemorrhage due to proteolysis of blood vessels or consumption of fibrinogen and other clotting factors, thus preventing clot formation (Markland, 1998). Moreover, L. muta venom induces clotting and these biological activities are associated with specific protease groups: the metalloprotease and serine protease. As observed, C. cervicornis extract and diterpenes inhibited clotting of fibrinogen triggered by one MCD of L. muta venom (Figure 1B) only at the 1:60 venom:alga ratio, the $C$. cervicornis extract's inhibition being more powerful. In contrast, at the 1:30 venom:alga ratio, no inhibition was seen (Figure 1B). In this way, we may infer that $C$. cervicornis compounds also interfere with serine protease enzymes. DMSO $(0.5 \% \mathrm{v} / \mathrm{v}$, final concentration) did not affect clotting induced by the L. muta venom (Figure 1B). 

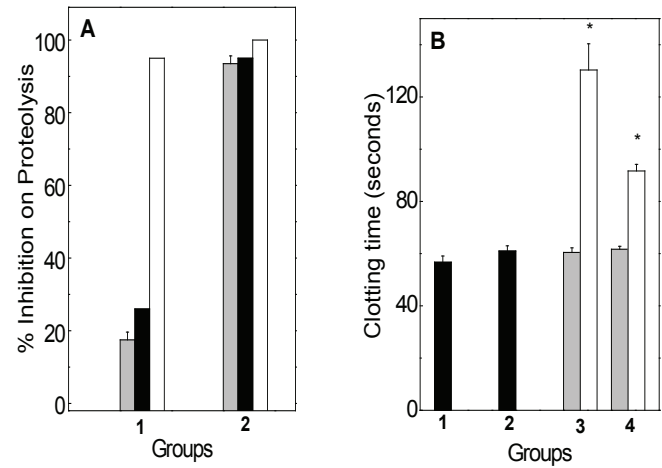

Figure 1. Antiproteolytic and anticlotting effects of $C$. cervicornis crude extract and isolated diterpenes isolinearol/ linearol. A. Inhibitory effect of C. cervicornis crude extracts (Group 1) or diterpenes isolinearol/linearol (Group 2) upon proteolysis induced by $L$. muta venom $(1.6 \mu \mathrm{g} / \mathrm{mL})$ at $1: 60$ (gray column), 1:120 (black column) or 1:180 (white column) venom:alga ratio (w/w). B. Inhibitory effect of $C$. cervicornis crude extracts (Group 3) or diterpenes isolinearol/linearol (Group 4) upon coagulation triggered by L. muta venom $(6 \mu \mathrm{g} / \mathrm{mL})$, at venom:alga ratio of 1:30 (gray column) and 1:60 (white column). Columns 1 and 2 represent coagulation induced by L. muta $(6 \mu \mathrm{g} / \mathrm{mL})$ in the presence of $150 \mathrm{mM} \mathrm{NaCl}$ or $0.5 \%$ DMSO (v/v, final concentration), respectively. Data are expressed as means \pm SEM of three individual experiments $(\mathrm{n}=3)$. *Significance level $(p<0.05)$, when compared to columns 1 and 2.

Table 1. Antihemolytic action of C. cervicornis crude extract and diterpenes against L. muta or LM-PLA -I.

\begin{tabular}{|c|c|c|c|c|}
\hline $\begin{array}{l}\text { Venom } \\
\text { source }\end{array}$ & $\begin{array}{c}\text { Concentration } \\
(\mu \mathrm{g} / \mathrm{mL})\end{array}$ & $\begin{array}{c}\text { Marine alga } \\
\text { source }\end{array}$ & $\begin{array}{l}\text { Concentration } \\
(\mu \mathrm{g} / \mathrm{mL})\end{array}$ & $\begin{array}{c}\% \\
\text { Inhibition } \\
\text { on } \\
\text { hemolysis }\end{array}$ \\
\hline \multirow{4}{*}{ L. muta } & \multirow{4}{*}{36} & \multirow{2}{*}{ C. cervicornis } & 360 & 0 \\
\hline & & & 720 & 0 \\
\hline & & \multirow{2}{*}{ Diterpenes } & 360 & 0 \\
\hline & & & 720 & 0 \\
\hline \multirow{4}{*}{$\begin{array}{c}\text { LM- } \\
\text { PLA }_{2}-\mathrm{I}\end{array}$} & \multirow{4}{*}{90} & \multirow{2}{*}{ C. cervicornis } & 900 & 0 \\
\hline & & & 1800 & 0 \\
\hline & & \multirow{2}{*}{ Diterpenes } & 900 & $25 \pm 4$ \\
\hline & & & 1800 & $60 \pm 4$ \\
\hline
\end{tabular}

Inhibitory effect upon hemolytic activity of L. muta crude venom or LM-PLA - I by $C$. cervicornis crude extracts or diterpenes at 1:10 or 1:20 venom:alga ratio (w/w). Data are expressed as mean \pm SEM of three individuals experiments $(n=3)$.

Figure 2 shows that $C$. cervicornis extract (187 $\mathrm{mg} / \mathrm{kg}$ ) and isolated diterpenes $(87 \mathrm{mg} / \mathrm{kg}$ ) fully protected mice from hemorrhage caused by L. muta venom (12 mg/ $\mathrm{kg}$ ). Curiously, the algal compounds (C. cervicornis extract and diterpenes) also prevented hemorrhage when L. muta venom equivalent to two MHD was injected into mice (data not shown). The animals that received only saline or C. cervicornis extract/diterpenes showed no hemorrhagic halo. We suggest that the inhibitory mechanism of action of $C$. cervicornis extract or diterpenes upon hemorrhagic activity may occur through an interaction between compounds in algae and metalloproteases in the venom by binding to the catalytic sites of these enzymes or by chelating metal ions essential for their enzymatic activity, since it is known from the literature that diterpenes may bind divalent metals (Borges et al., 2005).

In conclusion, bioactive compounds from the seaweed C. cervicornis appear to be a promising source of molecules to improve the current treatment against $L$. muta envenomation and useful as prototypes for designing new antiophidian molecules.

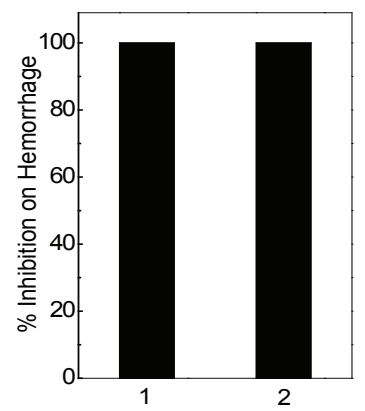

Figure 2. Antihemorrhagic effect of C. cervicornis crude extract and isolated diterpenes isolinearol/linearol. Inhibition on hemorrhage induced by L. muta venom $(12 \mathrm{mg} / \mathrm{kg})$ in the presence of $187 \mathrm{mg} / \mathrm{kg} \mathrm{C}$. cervicornis extract (column 1) or $87 \mathrm{mg} / \mathrm{kg}$ diterpenes isolinearol/linearol (column 2). Data are expressed as means \pm SEM of two individual experiments $(n=3)$.

\section{Acknowledgments}

This work was supported by the International Foundation for Science (IFS grant F/4571-1) and by the following Brazilian funding agencies: Conselho Nacional de Desenvolvimento Científico e Tecnológico, Fundação de Amparo à Pesquisa do Estado do Rio de Janeiro Carlos Chagas Filho, Coordenação de Aperfeiçoamento de Pessoal de Nível Superior and Universidade Federal Fluminense/ Pró-reitoria de Pesquisa e Pós-graduação e Inovação.

\section{References}

Abrantes JL, Barbosa JP, Cavalcanti DN, Pereira RC, Fontes CFL, Teixeira VL, Souza TML, Paixão ICNP 2010. The effects of the diterpenes isolated from the Brazilian brown algae Dictyota pfaffii and Dictyota menstrualis against the herpes simplex type-1 replicative cycle. Planta Med 76: 339-344.

Bianco EM, Rogers R, Teixeira VL, Pereira RC 2009. Antifoulant diterpenes produced by the brown seaweed Canistrocarpus cervicornis. J Appl Phycol 21: 341346.

Borges MH, Alves DL, Raslan DS, Piló-Veloso D, Rodrigues VM, Homsi-Brandeburgo MI, de Lima ME 2005. Neutralizing properties of Musa paradisiaca L. (Musaceae) juice on phospholipase $A_{2}$, myotoxic, 
hemorrhagic and lethal activities of crotalidae venoms. J Ethnopharmacol 98: 21-29.

Cirne-Santos CC, Souza TML, Teixeira VL, Fontes CFL, Rebello MA, Castello-Branco LR, Abreu CM, Tanuri A, Frugulhetti IC, Bou-Habib DC 2008. The dolabellane diterpene dolabelladienetriol is a typical noncompetitive inhibitor of HIV-1 reverse transcriptase enzyme. Antiviral Res 77: 64-71.

Damico DC, da Cruz Höfling MA, Cintra M, Leonardo MB, Calgarotto AK, da Silva SL, Marangoni S 2008. Pharmacological study of edema and myonecrosis in mice induced by venom of the bushmaster snake (Lachesis muta muta) and its basic Asp49 phospholipase A(2) (LmTX-I). Protein J 27: 384-391.

da Silva NM, Arruda EZ, Murakami YL, Moraes RA, El-Kik CZ, Tomaz MA, Fernandes FF, Oliveira CZ, Soares AM, Giglio JR, Melo PA 2007. Evaluation of three Brazilian antivenom ability to antagonize myonecrosis and hemorrhage induced by Bothrops snake venoms in a mouse model. Toxicon 50: 196-205.

de Oliveira AS, Cavalcanti DN, Bianco EM, De Paula JC, Pereira RC, Yonsehigue-Valentin, Y, Teixeira VL 2008. Chemical composition of diterpenes from the brown alga Canistrocarpus cervicornis (Dictyotaceae, Phacophyceae). Nat Prod Commun 3: 1469-1472.

Domingos TFS, Carvalho C, Moura LA, Teixeira VL, Pereira RC, Ramos CJ, Miranda ALP, Melo PA, Guimarães JA, Fuly AL 2009. Antilonomic effects of different Brazilian brown seaweeds crude extracts. Nat Prod Commun 4: 1075-1078.

Freitas OSP, Oliveira AS, De Paula JC, Pereira RC, Cavalcanti DN, Teixeira VL 2007. Chemical variation in the diterpenes from the Brazilian brown alga Dictyota mertensii (Dictyotaceae, Phaeophyta). Nat Prod Commun 2: 13-15.

Fuly AL, Francischetti IM, Zingali RB, Carlini CR 1993. Partial purification and some physicochemical properties of phospholipases $\mathrm{A}_{2}$ from the venom of the bushmaster snake (Lachesis muta). Braz J Med Biol Res 26: 459463.

Fuly AL, Machado OL, Alves EW, Carlini CR 1997. Mechanism of inhibitory action on platelet activation of a phospholipase $\mathrm{A}_{2}$ isolated from Lachesis muta (Bushmaster) snake venom. Thromb Haemost 78: 1372-1380.

Fuly AL, Miranda AL, Guimarães JA 2002. Purification and characterization of phospholpase $\mathrm{A}_{2}$ isoenzyme isolated from Lachesis muta snake venom. Biochem Pharmacol 63: 1589-1597.

Garcia ES, Guimarães JA, Prado JL 1978. Purification and characterization of a sulfhydryl-dependent protease from Rhodnius prolixus midgut. Arch Biochem Biophys 188: 315-322.

González del ValA, Platas G, BasílioA, CabelloA, Gorrochategui J, Suay I, Vicente F, Portilho E, Jiménez Del Rio M, Reina GG, Peláez F 2001. Screening of antimicrobial activities in red, Green and Brown macroalgue from Gram Canária (Canary Islands, Spain). Int Microbiol 4: 35-40.

Jongaramruong J, Kongkam N 2007. Novel diterpenes with cytotoxic, anti-malarial and anti-tuberculosis activities from a brown alga Dictyota sp. J Asian Nat Prod Res
9: $743-751$.

Jorge MT, Sano-Martins IS, Tomy SC, Castro SC, Ferrari RA, Ribeiro LA, Warrell DA 1997. Snakebite by the bushmaster (Lachesis muta) in Brazil: case report and review of the literature. Toxicon 35: 545-554.

Kondo H, Kondo S, Ikezawa H, Murata R, Ohsaka A 1960. Studies on the quantitative methods for determination of hemorrhagic activity of Habu snake venom. Jpn $J$ Med Sci Biol 13: 43-51.

Markland FS 1998. Snake venoms and the hemostatic system. Toxicon 36: 1749-1800.

Mayer AM, Rodrígues AD, Berlinck RG, Hamann MT 2007. Marine compounds with anthelmintic, antibacterial, anticoagulant, antifungal, anti-inflammatory, antimalarial, antiplatelet, antiprotozoal, antituberculosis, and antiviral activities; affecting the cardiovascular, immune and nervous systems, and other miscellaneous mechanisms of action. Comp Biochem Physiol 145: 553-581.

Ministério da Saúde 2001. Manual de diagnóstico e tratamento de acidentes por animais peçonhentos. $2^{\text {nd }}$ ed. Brasília: FunasA, $120 \mathrm{p}$.

Moura LA, Sanchez EF, Bianco EM, Pereira RC, Teixeira VL, Fuly AL 2010. Antiophidian properties of a dolastane diterpene isolated from the marine brown alga Canistrocarpus cervicornis. Biomed Pharmacother 23: doi:10.1016/j.biopha.2010.09.023.

Nikai T, Mori N, Kishida M, Sugihara H, Tu AT 1984. Isolation and biochemical characterization of hemorrhagic toxin from the venom of Crotalus atrox. Arch Biochem Biophys 231: 309-311.

Ortiz-Ramirez FA, Cavalcanti DN, Villaça RC, De Paula JC, Yonsehigue-Valentin Y, Teixeira VL 2008. Chemical variation in the diterpenes from the Brazilian brown alga Dictyota menstrualis (Dictyotaceae, Phaeophyceae). Nat Prod Commun 3: 1879-1884.

Rocha FD, Soares AR, Houghton PJ, Pereira RC, Kaplan MA, Teixeira VL 2007. Potential cytotoxic activity of some Brazilian seaweed on human melanoma cells. Phytother Res 21: 170-175.

Teixeira VL, Almeida SAS, Kelecom A 1990. Chemosytematic and biogeographic studies of the diterpenes from the marine brown alga Dictyota dichotoma. Biochem Syst Ecol 18: 87-92.

Teixeira VL, Tomassini T, Fleury BG, Kelecom A 1986. Dolastane and secodolastane diterpenes from the marine brown alga, Dictyota cervicornis. J Nat Prod 4: 570-575.

Vallim MA, De Paula JC, Pereira RC, Teixeira VL. 2005. The diterpenes from Dictyotacean marine brown algae in the tropical Atlantic American region. Biochem Sys Ecol 33: 1-16.

\section{* Correspondence}

André Lopes Fuly

Programa de Pós-graduação em Biologia Marinha, Instituto de Biologia

Universidade Federal Fluminense, 24020-150 Niterói-RJ, Brazil

andfuly@vm.uff.br

Tel. +552126292294

Fax: +55 2126292376 